\title{
Eszközöktől a jóllétig. A helyi gazdaságfejlesztés körvonalai a képességszemléletben
}

\section{From means to well-being: local economic development - the capability approach}

\author{
GÉBERT JUDIT, BAJMÓCY ZOLTÁN, MÁLOVICS GYÖRGY, \\ PATAKI GYÖRGY
}

\begin{abstract}
GÉBERT Judit: egyetemi adjunktus, Szegedi Tudományegyetem, Gazdaságtudományi Kar Kutatóközpont; 6722 Szeged, Kálvária sgt. 1.; gebert.judit@eco.u-szeged.hu BAJMÓcY Zoltán: egyetemi docens, Szegedi Tudományegyetem, Gazdaságtudományi Kar Kutatóközpont; 6722 Szeged, Kálvária sgt. 1.; bajmocyz@eco.u-szeged.hu MÁLOVICS György: egyetemi docens, Szegedi Tudományegyetem, Gazdaságtudományi Kar Kutatóközpont, 6722 Szeged, Kálvária sgt. 1.; malovics.gyorgy@eco.u-szeged.hu PATAKI György: egyetemi docens, Budapesti Corvinus Egyetem, Vállalatgazdaságtan Intézet, Döntéselmélet Tanszék; Environmental Social Science Research Group (ESSRG); 1093 Budapest, Fővám tér 8.; gyorgy.pataki@uni-corvinus.hu
\end{abstract}

KULCSSZAVAK: helyi gazdaságfejlesztés, helyi tervezés, képességszemlélet, deliberatív részvétel

ABSZTRAKT: A legtöbb szerző egységesen a helyi gazdaságfejlesztés céljaként a helyben élők helyzetének javítását jelöli meg. Ugyanakkor nem tisztázzák sem azt, hogy mit értenek a helyben élők jólétén, sem pedig azt, hogy a javasolt beavatkozások hogyan hatnak arra. Tanulmányunkban a helyi gazdaságfejlesztés jólétértelmezését fejtjük ki az egyik legnagyobb hatású kortárs közgazdaságtani/filozófiai gondolatrendszer, a képességszemlélet alapján. Azt vizsgáljuk, hogy a jólét fogalmával kapcsolatos különböző előfeltevések hogyan befolyásolják a helyi gazdaságfejlesztés célját, fókuszát és munkamódszerét.

Tanulmányunkban megmutatjuk, hogy a képességszemléletre alapozott helyi gazdaságfejlesztés jelentősen különbözik az általunk eszközorientáltnak nevezett modelltől. Szemben az értéksemlegesnek és objektívnak gondolt szokásos fejlesztési megközelítésekkel, a képességszemlélet-alapú helyi gazdaságfejlesztés emberi értékeket középpontba állító, nyíltan értékvezérelt, közösségközpontú megközelítést kínál. Amellett érvelünk, hogy a képességszemlélet melletti elköteleződés nagyban segítheti a helyi fejlesztésekkel kapcsolatos kudarcok megértését és hozzájárulhat ahhoz, hogy olyan megoldások szülessenek, amelyek az eszközorientált modellben felismerhetetlenek. Rámutatunk arra is, hogy az érintettek aktív részvétele (a problémafeltárástól kezdve egészen a megoldások megtalálásáig és végrehajtásáig) a fejlesztés eredményétől függetlenül is értékes tevékenység, amely elősegitheti a helyi gazdaságfejlesztés sikerét.

Judit GÉBERT: senior lecturer, Research Centre, Faculty of Economics and Business Administration, University of Szeged; Kálvária sgt. 1., H-6722 Szeged, Hungary; gebert.judit@eco.u-szeged.hu

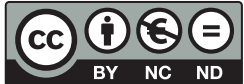


Zoltán BAJMÓcY: associate professor, Research Centre, Faculty of Economics and Business Administration, University of Szeged; Kálvária sgt.1., H-6722 Szeged, Hungary; bajmocyz@eco.uszeged.hu

György MÁLOVICS: associate professor, Research Centre, Faculty of Economics and Business Administration, University of Szeged; Kálvária sgt.1., H-6722 Szeged, Hungary; malovics.gyorgy@eco.uszeged.hu

György PATAKI: associate professor, Department of Decision Sciences, Institute of Business Economics, Corvinus University of Budapest and Environmental Social Science Research Group (ESSRG); Fővám tér 8., H-1093 Budapest, Hungary; gyorgy.pataki@uni-corvinus.hu

KEYWORDS: local economic development, capability approach, deliberative participation

ABSTRACT: Most authors agree that the goal of local economic development is increasing welfare, standard of living or the quality of life of local inhabitants. But when we look for a rationale of well-being (or welfare, standard of living, quality of life) we cannot find any tangible definition in the literature on local economic development. Mostly, the practice of, and the theorising about, local economic development pay attention only to the means of well-being. For instance: How can competitiveness or regional innovation capacity be increased, how can the local economy be restructured, how can less-developed regions be developed? Means are in the focus of mainstream theories of local economic development because according to those theories, there is a positive linear relationship between means and well-being: improvement of means results automatically in higher well-being.

We call mainstream theories of local economic development means-oriented because their focus is on means and not ends (well-being). In opposition to the means-oriented approaches, we try to establish a model of local economic development which is based on the notion of wellbeing, based on the capability approach formulated by Amartya Sen.

We had two research questions. (1) What are the goals, the processes and methods of local economic development according to the capability approach? (2) What are the consequences of the capability-based local economic development for the practice of local economic development in Hungary?

In our paper, we argue that the goal of local economic development is the enhancement of capabilities of local inhabitants. The process of local economic development consists of three steps. (1) Identifying relevant capabilities with deliberative participation. (2) Analysing the relationship between means and relevant capabilities. (3) Iteration of the previous two steps.

We suggest that it is possible to base local economic development on the capability approach, which focuses both on means - and the circumstances of the use of means. This capability-based approach creates an openly value-driven and community-centred model. An essential part of this approach is to specify the valuable capabilities and most important values that come along with deliberative participation. We show that local development should not focus only on one aspect (for instance economic growth) and that the information taken into consideration in current practice is insufficient for a successful local development process. So, our perspective provides guidelines to broaden the informational base for decisions on local development.

\section{Bevezetés}

A hazai és a nemzetközi szakirodalom meglehetősen egységes abban a tekintetben, hogy a helyi gazdaságfejlesztés célja a helyben élők jólétének, életszínvonalának vagy életminőségének javítása (Bajmócy 2011; Mezei 2006; Swinburn, Goga, Murphy 2006). Ám amikor azt keressük a helyi gazdaságfejlesztés 
szakirodalomában, hogy mi is értendő „jólét”-en, nem sok használható meghatározást találunk.

A helyi gazdaságfejlesztés gyakorlata és az azzal kapcsolatos elméletalkotás jelentős része szinte kizárólag azokkal az eszközökkel foglalkozik, melyek révén az érintettek jóléte jó eséllyel nő. Például: hogyan javítható a versenyképesség, hogyan fokozható a térségek innovációs képessége, hogyan lehet átstrukturálni a térség gazdaságát, hogyan zárkózhatnak fel a kevésbé fejlett térségek stb. Az uralkodó megközelítés fókuszában azért állnak az eszközök, mert e megközelítés hívei szerint egyértelmű kapcsolat van az eszközök és a jólét között: a fentebb említett eszközök javulása automatikusan a jólét növekedésével jár.

Tanulmányunkban eszközorientáltnak nevezzük a helyi gazdaságfejlesztés összes olyan modelljét, amely az előbb felsorolt eszközökkel foglalkozik. Az ilyen eszközorientált modellekkel szemben a helyi gazdaságfejlesztés alapvonásait oly módon kíséreljük meg felvázolni, amely az eszközök helyett a jóllét ${ }^{1}$ fogalmából indul ki. Ennek során a képességszemlélet jóllétértelmezéséből igyekszünk levezetni a helyi gazdaságfejlesztés körvonalait.

Két kutatási kérdésünk van:

- A képességszemlélet alapján hogyan határozhatók meg a helyi gazdaságfejlesztés céljai, folyamata és módszerei?

- Ennek alapján milyen - a hazai helyzet számára is meghatározó - következtetések vonhatók le a helyi gazdaságfejlesztés gyakorlata számára?

Tanulmányunk második részében röviden bemutatjuk a képességszemlélet témánk szempontjából alapvető elemeit. A harmadik részben a képességszemléletre építő helyi gazdaságfejlesztés célját és folyamatát próbáljuk tisztázni. A következő részben felvázoljuk a képességszemlélet-alapú helyi gazdaságfejlesztés vizsgálati területét és döntéshozatali eljárásait. Az ötödik részben hazai jelentőségü gyakorlati következményekre térünk ki, majd az utolsó részben - a következtetések levonása mellett - rámutatunk a képességszemlélet-alapú és az eszközorientált megközelítés legfőbb különbségeire.

\section{A képességszemlélet alapjai}

Az elmúlt két évtizedben a képességszemlélet az egyik legnagyobb hatású elmélet volt a társadalomtudományokban és a közpolitikai tervezésben. A koncepciót a közgazdaságtudományi Nobel-díjas Amartya Sen dolgozta ki, de mai formájához számtalan kutató és döntéshozó járult hozzá; a vonatkozó szakirodalom rendkívül gazdaggá vált. A képességszemlélet a társadalomtudományok több területén fejtette ki hatását, többek között a jólléttel, emberi fejlődéssel, szegénységgel, társadalmi igazságossággal kapcsolatos témákban.

A megközelítés két központi fogalma a képesség (capability) és a tevékenység/létállapot (functioning). „A tevékenység/létállapot egy személy életének rész- 
letét reprezentálja - pontosabban azokat a dolgokat, amelyeket sikerül végrehajtania, vagy amely állapotokat sikerül elérnie az élete során" (Sen 1993, 31.). Tulajdonképpen a tevékenység/létállapot olyan tevékenységeket (doings) és létállapotokat (beings) jelent, amelyeket a személy vagy személyek értékelnek; vagyis ezek egy ember létének alapelemei. A tevékenység/létállapot kifejezés nagyon egyszerü dolgokra is utalhat, például jól tápláltnak, egészségesnek lenni, tudni írni-olvasni stb. De összetettebb tevékenységek/létállapotok is elképzelhetőek, úgymint diplomát szerezni, részt venni a közösség életében, önbizalommal rendelkezni vagy szégyen nélkül megjelenni a közösség elött.

„A képesség² kifejezés a tevékenységek/létállapotok alternatív kombinációira vonatkozik, amelyeket egy személy el tud érni, és amelyek közül választhat egy kollekciót" (Sen 1993, 31.). Így a képességek jelentik az összes elérhető alternatív életmódot, amelyet egy személy folytathat; vagyis egy személy képességei megmutatják, hogy ténylegesen mit tud megtenni, illetve mivé tud válni. Másképpen: a képességek jelölik a valódi lehetőségeket vagy pozitív szabadságokat az életben, amelyekkel különböző tevékenységek/létállapotok valósíthatóak meg.

Képességeink halmaza nem csak a ténylegesen választott tevékenységek/létállapotok miatt értékes (Sen 1993, 1999a). A ténylegesen megvalósított tevékenység/létállapot értékét sokszor éppen az adja, hogy az egyénnek lehetősége lett volna másik tevékenységet/létállapotot választani. Sen (1999a) példájával élve a politikai célok miatt éhségsztrájkot folytató Gandhi és az éhező indiai nincstelen helyzete látszólag azonos: egyik sem eszik. Gandhi cselekedetének viszont pontosan az adja értelmét, hogy választhatta volna azt az alternatívát is, hogy eszik.

A képességszemléletben a jóllétet az határozza meg, hogy milyen képességekkel rendelkezünk, vagyis van-e lehetőségünk elérni a számunkra értékes tevékenységeket/létállapotokat. Ennek következtében a fejlődési folyamat célját úgy határozhatjuk meg mint a képességek kiterjesztését, vagyis hogy minél több értékes lehetőség közül választhassanak a közösség tagjai (Sen 1999a).

Sen kiemelt jelentőséget tulajdonít az eszközök és a célok közötti különbségtételnek (Robeyns 2005; Sen 1995, 1999a). Például a táplálék eszköz ahhoz, hogy valaki elérje a jóltápláltság állapotát, vagy a bicikli eszköz ahhoz, hogy valaki birtokolja a mobilitás képességét. Ennek megfelelően nem az a fontos, hogy milyen eszközökkel rendelkezünk, hanem annak van jelentősége az emberi élet számára, hogy azokkal az eszközökkel mit tudunk kezdeni. Maga a cél tehát az értékes tevékenység/létállapot (a példában a jóltápláltság vagy a mobilitás), az eszköz (a példában a táplálék vagy a bicikli) a célhoz képest csupán instrumentális értékkel rendelkezik.

Az a különbség, hogy mi számít eszköznek, és mi célnak, nem mindig egyértelmű egy elemzés során. Például az oktatás egyrészről lehet eszköz, mert általa az egyénnek jobb esélyei vannak a munkaerőpiacon, nagyobb hozzáadott értéket tud elóállítani, nagyobb munkabért tud megkeresni, de tanult embernek lenni önmagában is értékesnek tekinthető cél. Az, hogy mi számít a képességszemléletben célnak vagy eszköznek, értékelés kérdése (Robeyns 2005). 
Azt, hogy egy egyén milyen mértékben tudja a rendelkezésére álló eszközöket értékes cselekvésekké és létállapotokká konvertálni, különböző átváltási tényezók (conversion factors) befolyásolják (Robeyns 2005; Sen 1995, 1999a). A példánál maradva: hogy egy adott élelemmennyiséggel jól táplált lesz-e valaki, az függ többek között fizikai állapotától, személyes jellemzőitől. Egy gyermeket váró nő nem lesz jól táplált ugyanazzal a mennyiségü étellel, mint amikor még nem várt gyermeket. Társadalmi szinten ez ugyanúgy igaz: bizonyos mennyiségủ élelem elegendő lehet egy meleg éghajlaton élő közösség számára, ám ugyanez már kevésnek bizonyulhat a hideg éghajlat alatt élőknek. Hogy mindenki jól táplált lesz-e a társadalomban, az élelem társadalmon belüli eloszlásától vagy az elosztást befolyásoló társadalmi normáktól függ (Sen 1999a).

Az átváltási tényezők tulajdonképpen azt a kontextust írják le, amelyben egy eszköz (vagy erőforrás) felhasználása megtörténik. Ezért van fontos üzenete a közgazdaságtan számára, amelyet általában a szűkös erőforrások elosztásaként fognak fel (Samuelson, Nordhaus 2009). Az a tény tehát, hogy az embernek lehetősége van valamilyen értékes tevékenység/létállapot elérésére, két dologtól függ: a rendelkezésre álló eszközeitől és az átváltási tényezőktől. A kettő együtt, vagyis az eszközök és átváltási tényezők határozzák meg az emberek képességeit. A képességek fogalma tehát az eszközök lehetséges felhasználási lehetőségeit írja le, de nem mond semmit arról, hogy az egyén melyik felhasználási lehetőség mellett dönt ténylegesen.

A képességszemlélet egyik üzenete a döntéshozatal számára az, hogy az emberek aktív cselekvők (agents) a társadalomban, képesek előmozdítani a saját ügyeiket, nem tekinthetünk rájuk úgy, mint a fejlesztések passzív befogadóira (Sen 1999a). Ennélfogva az emberek saját stratégiáira kell építkezni, képessé kell tenni őket arra, hogy változtassanak a sorsukon, és éljenek a lehetőségeikkel. Ahogy Sen fogalmaz: , a [n]agyobb szabadság elősegíti az emberek tehetségét és lehetőségét arra, hogy segítsenek magukon, és befolyással legyenek a világra. Ezek központi dolgok egy fejlődési folyamatban" (Sen 1999a, 18.).

Azt a képességet, hogy a cselekvő személynek tényleges lehetősége van eljárni a saját ügyeiben, a képességszemlélet a „cselekvésre való szabadság” (agency) kifejezéssel jelöli, amely más szavakkal a saját ügyeink tevékeny előmozdításának lehetőségét jelenti. A személy mint cselekvő egy a sok lehetséges képesség közül, de azok között speciális helyet foglal el, mert alapja sok más képességnek (Robeyns 2005; Sen 1995).

A képességszemlélet irodalmában nagy jelentősége van annak, hogy a cselekvő személy milyen célokat tart értékesnek, illetve hogy a képességszemlélet szerinti elemzésben hogyan határozódnak meg ezek a célok. A szakirodalom szerint az egyik módszer erre a deliberatív társadalmi részvétel (Robeyns 2005). ${ }^{3}$

Sen (1999a, 2008) amellett érvel, hogy ideálisan az értékes cselekvések és létállapotok meghatározása demokratikus folyamatok, deliberáció eredménye. Vagyis az embereknek társadalmi vitában kell meghatározniuk, hogy milyen értékeket tartanak fontosnak a saját közösségükben az adott körülmények kö- 
zött. Egyrészt így lehetőség nyílik az értékek explicitté tételére, megvitatására, konszenzusos elfogadására. Másrészt a cselekvő személynek lehetősége van politikai színtérre vinni a saját céljait és lépéseket tenni azok elérésének érdekében.

A képességszemlélet nyitottsága azt is jelenti, hogy az értékes tevékenységek/létállapotok megállapítása nemcsak az egyénektől, hanem az értékelendő szituációktól, körülményektől is függ (Alkire 2007). Például a nemi egyenlőtlenségek vizsgálata során más lehetőségekre kell fókuszálni egy nyugat-európai ország és egy ázsiai ország esetében.

A képességszemléletben a deliberáció nem egyszeri társadalmi folyamatot jelent, még csak nem is meghatározott időnkénti beavatkozást, mint amilyenek a négyévenkénti választások. Az sokkal inkább egyfajta folyamatos, iteratív részvétel (participation) a közösségi döntéshozási folyamatokban. A képességszemlélet az értékes tevékenységek/létállapotok folyamatos megvitatását, az elért eredmények felülvizsgálatát követeli meg. Ehhez elengedhetetlenül szükséges a deliberatív részvételi folyamatok megléte a döntéshozatalban.

Az utóbbi évtizedben több módon is operacionalizálták a képességszemléletet. $\mathrm{E}$ kísérletek jelentős része a képességekben megfogalmazott jóllét mérésére irányult (Robeyns 2006; Stiglitz, Sen, Fitoussi 2009). Több olyan publikáció is született, amelyek a képességszemlélet és a regionális tudomány kapcsolódási pontjait tárták fel (Biggeri, Ferrannini 2014b; Frediani 2010). Néhány hazai szerző a képességszemléletet véve alapul a kistérségi szintű jóllét vizsgálatát tűzte ki célul (Garami 2009; Gébert, Málovics, Fáskerti 2012; Nagy, Koós 2014; Szirmai 2015). Tanulmányunkban mi nem a képességekben megfogalmazott jóllét mérésével foglalkozunk, hanem a képességszemlélet-alapú helyi gazdaságfejlesztés elméleti alapjainak és logikájának kidolgozásával.

\section{Jólét, jóllét, életszínvonal és életminőség a helyi gazdaságfejlesztésben}

A helyi gazdaságfejlesztés irodalma egységesen azt tekinti célnak, hogy a helyben élőknek ,jobb legyen”, ám igen kevés figyelmet szentel annak, hogy ezen mit is értsünk. Ráadásul számos gazdaságfejlesztési munkában szinonimaként jelennek meg a jólét, életszínvonal, életminőség fogalmai (Lengyel 2010; Swinburn, Goga, Murphy 2006), holott más tudományterületeken e fogalmak jelentése pontos és egymástól élesen különböző. A jólét (welfare) egyértelmüen a haszonelvű alapokon nyugvó közgazdaságtan kategóriája (Hausman, McPherson 1996), így a középpontban az egyén hasznossága áll. Az életszínvonal (standard of living) többnyire kifejezetten anyagi szempontokra koncentrál, így a jólétet a reáljövedelemmel kapcsolja össze. Az életminőség (quality of life) általában az észlelt elégedettségre, boldogságra utal (Layard 2006). A szintén gyakran megjelenő jóllét (well-being) pedig az élet számos olyan as- 
pektusát is felöleli, amely túlmutat az anyagias szempontokon, és erősen kapcsolódik bizonyos jólétértelmezésekhez, mint például Sen képességszemléletéhez (Sen 1995, 1999a).

A jólét fogalmának tisztázatlansága miatt nem ítélhető meg, hogy egy beavatkozás nyomán végül is jobb lett-e a helyben élők helyzete, vagy sem. Úgy tűnik tehát, hogy a helyi gazdaságfejlesztés szakirodalma e kérdést vizsgálati körön kívülinek tekinti, miközben saját célmeghatározását éppen erre építi. $\mathrm{E}$ látszólagos ellentmondást szerintünk két tényező magyarázhatja, és mindkettő problémákat vet fel.

Az egyik lehetséges magyarázat, hogy a helyi gazdaságfejlesztés hallgatólagosan elfogadja a közgazdaságtan domináns (haszonelvü) jólétértelmezését, és ezt összeköti azzal a szintén általános gyakorlattal, hogy a reáljövedelmet a hasznosság közelíto mértékének tekinti (Sen 1999a). Ekkor jóléti értelemben könnyen legitimálhatóak az olyan célok, mint a növekedés vagy a versenyképesség, hiszen az egy före jutó reáljövedelem növekedése szükségszerủen össztársadalmi jóléti nyereséget eredményez. ${ }^{4} \mathrm{~A}$ hasznosságon alapuló, illetve a reáljövedelmre támaszkodó értékelés azonban az utóbbi évtizedekben több kritikát kapott (Rawls 1971, 2001; Sen 1999a). A kritikák egyrészt a haszonelven nyugvó értékelés és a közösségi döntéshozatal közti feszültségre, másrészt a hallgatólagosan elfogadott normatív előfeltevésekre, harmadrészt a figyelembe vett információk túlságosan szük voltára mutatnak rá (Hausman, McPherson 1996; Rawls 1982; Sen 1979, 1999a).

A másik lehetséges magyarázat szerint a „Mitől lesz jobb a közösség helyzete?” kérdést a helyi gazdaságfejlesztés szakirodalma a politikai színtérre tartozónak véli. A célok tehát a politikai vitákban körvonalazódnak, a helyi gazdaságfejlesztés készen kapja azokat, így megfelelőségük vizsgálata nem képezheti részét a helyi gazdaságfejlesztés szűken vett szakterületének. E megközelítés abból az általános nézetből táplálkozik, amely elkülöníti a szakértői tudás létrehozásának (objektív és értéksemleges) színterét a közakarat kifejeződésének (értékek és érdekek által befolyásolt politikai) színterétől. ${ }^{5} \mathrm{E}$ megközelítés azonban szintén széles körű kritikák tárgya. A téma szűken vett hazai szakirodalmában Faragó (2005) nagy hatású kritikáját elsősorban a társadalmi konstruktivista érvekre alapozta.

Az érvényesnek tekintett tudás előállításának és a közakarat kimunkálásának szükségszerü kapcsolatára általános értelemben a tudomány-és technikatanulmányok (science and technology studies, STS) mutatnak rá (Latour 1993, 2005). Széles körben tárgyalt téma, hogy komplex és bizonytalan helyzetekben nem tartható a tudományos (szakértői) úton előállított tudás érték- és érdeksemleges voltáról alkotott kép, sem az a feltevés, hogy a tudomány minden esetben képes lenne objektív képet adni a világ jelenlegi és jövőbeni állásáról (Callon, Lascoumes, Barthe 2011; Funtowitz, Ravetz 1993; Ravetz 2004). A helyi gazdaságfejlesztési beavatkozásoknak viszont szükségszerü velejárója a komplexitás és a bizonytalanság. Ezt részletesen tárgyalja Lengyel és Bajmócy (2013), valamint Elekes és Bajmócy (2013). 
Szerintünk a képességszemlélet egyik legnagyobb előnye éppen abban áll, hogy nyíltan szembesít az alkalmazott normatív előfeltevésekkel, és azokat vita tárgyává teszi. Nem feltételezi a szakértői munka és az értékekről, érdekekről szóló viták teljes függetlenségét. A szakértői modellek jóllétről alkotott implicit feltevései hatással vannak a politikai színtérre, keretezik az ott zajló vitákat. ${ }^{6}$ A szakértő továbbá nyíltan felhasználhatja a közösség kezében meglevő tudást. A képességszemlélet jelentősége abban áll, hogy egy ilyen szituációban segít rendszerezni az érveket, szempontokat.

Mindez különösen fontos azért is, mert a helyi gazdaságfejlesztés jelenlegi irodalmában (a pozitivista retorika fenntartása mellett) sajátosan keveredik a leíró és előírő jelleg (Gébert 2015). A jólétnövelő cél előírása már önmagában is ezt eredményezi. Ám ennél még érdekesebb a viszonylag magas foglalkoztatottság megjelenése a versenyképességi megközelítésekben (Lengyel 2010; Swinburn, Goga, Murphy 2006). Minthogy a növekvő reáljövedelmet a foglalkoztatottság növelése nélkül is el lehet érni, így a magas szintű foglalkoztatottság nem a gazdasági hatékonyság feltétele, hanem társadalmi cél. Ennélfogva a foglalkoztatás növelésének célja társadalmi értékként és nem hatékonysági feltételként került a helyi gazdaságfejlesztés elméletébe. ${ }^{7}$

\section{A helyi gazdaságfejlesztés célja a képességszemlélet alapján}

A helyi gazdaságfejlesztés általánosan megfogalmazott célja (a helyben élők helyzetének javítása) a képességszemléletben a helyben élők képességeinek kiterjesztését jelenti. Az általános cél tehát szubsztantív, pontosan definiált tartalmat kap, mégpedig a helyben élők tényleges lehetőségeinek kiterjesztését.

Fontos, hogy a cél a közösség által értékesnek tartott tevékenységekre/létállapotokra való képességre vonatkozik: nemcsak úgy általában az emberi képességek kibontakoztatására, hanem a helyi közösség által értékesnek tartott tevékenységekre/létállapotokra vonatkozó tényleges lehetőségre. Ennélfogva a képességszemléletre alapozott helyi gazdaságfejlesztés emberi értékeket figyelembe vevő, értékvezérelt, közösségalapú fejlesztést jelent, szemben az értéksemlegesnek tartott hagyományos fejlesztési megközelítésekkel.

Így a helyi gazdaságfejlesztés a képességszemlélet alapján a következő: a helyi gazdasági folyamatokba történő olyan közösségi beavatkozás, amely hozzájárul a közösség által jó okkal értékesnek tartott képességek kiterjesztéséhez. E meghatározásnak két lényegi eleme van, amely további rövid magyarázatot igényel.

Egyrészt felhívja a figyelmet, hogy a gazdasági folyamatokba történő beavatkozás nem attól kívánatos, hogy bővíti a gazdasági lehetőségeket (pl. jövedelmet, foglalkoztatást), hanem attól, hogy kiterjeszti azon értékesnek tartott dolgok körét, amelyet a helyi közösség tagjai ténylegesen megtehetnek vagy elérhetnek.

A képességszemléletben a gazdagság és a jóllét viszonya összetett: jóllétünket a gazdagságon kívül más is befolyásolja, illetve sok mindentől függ, hogy 
a nagyobb gazdagsággal tényleg tudjuk-e jóllétünket növelni (Sen 1999a). Így a jövedelemnövelés akkor sem lehet kívánatos, ha az a jóllétünket befolyásoló más értékes tényezők rovására (pl. a szabadságjogok korlátozása, az egészséges környezethez való lehetőség csökkenése révén) történik, és akkor sem, ha a gazdagsággal nem tudjuk képességeinket bővíteni (mert személyes vagy környezeti átváltási tényezőink korlátoznak benne). Ilyen értelemben a képességszemlélet a gazdasági folyamatokkal való foglalkozást kontextusba helyezi, rámutat más, jó okkal értékesnek tekinthető területekkel való összetett viszonyokra.

A helyi gazdaságfejlesztés uralkodó megközelítései értelmezésünkben eszközorientált megközelítések, hiszen fókuszukban azok az eszközök állnak (jövedelem, infrastruktúra, munkahely, technológiai innovációk; vagy az ezeket létrehozó versenyképesség, innovációs képesség stb.), amelyeket az emberek felhasználhatnak céljaik elérése érdekében. Fontos megjegyezni, hogy ez az elnevezés csak a képességszemlélet felől tekintve helytálló. Amit a képességszemlélet alapján mi eszköznek nevezünk, az az eszközorientált megközelítés számára maga a cél.

A regionális tudományban a versenyképesség értelmezésébe - a reáljövedelmen és a foglalkoztatottságon kívül - egyre inkább beleértenek olyan szempontokat, mint a tudás, a jogrendszer, a mobilitás vagy a tiszta környezet (N. Kovács 2015). A képességszemlélet-alapú helyi gazdaságfejlesztés azonban az összes ilyen versenyképességi modelltől különbözik, mert az értékes tevékenységekre/létállapotokra helyezi a hangsúlyt és nem csupán az ahhoz szükséges eszközökre. Mindazok a tényezők, amelyekre ezek a versenyképességi modellek fókuszálnak, a képességszemlélet szempontjából csupán eszközök az értékes tevékenységek/létállapotok eléréséhez. Ezért nevezzük a helyi gazdaságfejlesztés versenyképesség-alapú megközelítéseit eszközorientált megközelítéseknek.

A fenti meghatározás másik fontos eleme a ,jó okkal” kifejezés. A „jó okkal” kifejezés a helyi gazdaságfejlesztés fenti definíciójában arra utal, hogy az értékes tevékenységek/létállapotok kiválasztása nem önkényes és nem véletlenszerü. Sen (1999a) megközelítésében csak akkor tudjuk saját álláspontunkat felelősen kialakítani és közösségi döntéseket hozni, ha módunk van mások érveinek megismerésére, megvitatására, saját korábbi álláspontunk szükség szerinti felülvizsgálatára. Azaz a ,jó okkal” azt jelenti, hogy a közösség tagjai megfontolt, több szempontból megvizsgált és megvitatott (vagyis deliberált) döntéseket hoznak a helyi gazdaságfejlesztés céljával kapcsolatban.

A deliberatív részvételhez szorosan kapcsolódik az információs bázis (informational basis) fogalma. Egy döntés vagy értékelési eljárás információs bázisa arra utal, hogy az információk mely körét vettük figyelembe, és ezáltal mely információkat hagytuk figyelmen kívül (Sen 1995). A képességszemlélet szerint az értékelési eljárásnak a lehető legszélesebb információs bázison kell nyugodnia.

A jó okkal értékesnek tartott szempontok kimunkálása hosszas közösségi tanulási folyamat eredménye lehet. A képességszemléletből tehát az 
következik, hogy a fejlesztés során célszerủ intézményesen törekedni az információs bázis bővítésére, mindig késznek kell lenni pótlólagos szempontok megvitatására.

\section{A helyi gazdaságfejlesztés folyamata a képességszemlélet alapján}

A képességszemléletre építő helyi gazdaságfejlesztés kiindulópontját az eszközök helyett a képességek jelentik (1. ábra). Az első lépés tehát annak meghatározása, hogy a fejlesztés mely - a közösség tagjai által fontosnak tartott - képességekhez kíván hozzájárulni. Ennek tisztázása olyan tudást követel meg, amely nem áll rendelkezésre előre adottan, és főként nem a szakértő kezében. Ez elengedhetetlenné teszi a deliberatív részvételt a helyi gazdaságfejlesztésben (Bajmócy, Gébert 2014).

A második lépés a helyi gazdaságfejlesztés eszközeinek vizsgálata. Fontos hangsúlyozni, hogy nem az eszközök megteremtése önmagában a cél, hanem az eszközök célokhoz rendelése. Vagyis nem az egyes eszközök meglétén vagy birtoklásán van a hangsúly, hanem azon, hogy az eszközök, fejlesztések milyen értékes cselekvéseket és létállapotokat tesznek elérhetővé. A helyi gazdaságfejlesztésben eszközön értünk minden olyan fizikai tárgyat vagy intézményt, amely hozzájárul a helyben élő lakosok képességeinek bővüléséhez.

1. ábra: Az eszközorientált és a képességszemléleten alapuló helyi gazdaságfejlesztés logikája Local economic development, based on the means-oriented and the capability approach

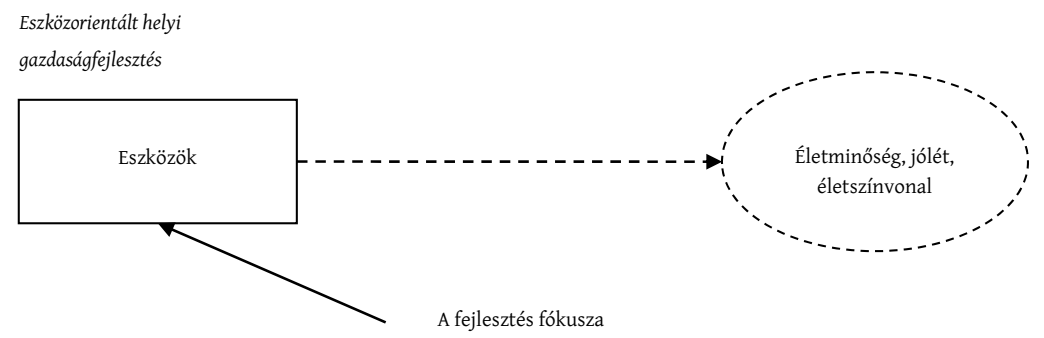

Képességszemlélet alapú helyi

gazdaságfejlesztés

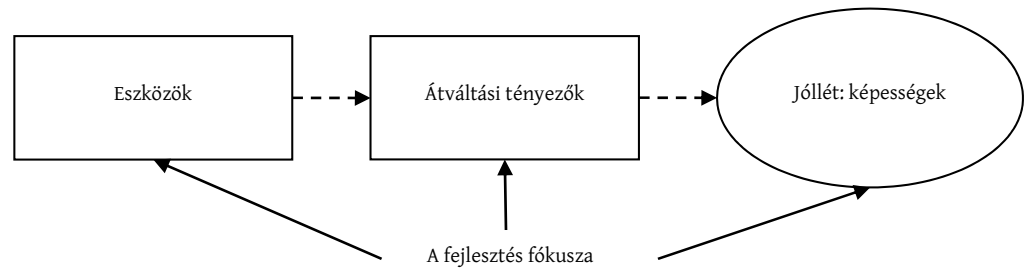

Forrás: saját szerkesztés. 
Például: utak, hidak, középületek, közösségi terek, jogrendszer vagy akár döntéshozó intézmények. De ide tartozik a jövedelem is, hiszen a képességszemlélet megközelítésében a jövedelem nem önmagában vett cél, hanem eszköz ahhoz, hogy elérjük az értékesnek tartott tevékenységeket/létállapotokat.

Elsőre talán szőrszálhasogatásnak tűnik, hogy az eszközök helyett az eszközök használatára fókuszál a képességszemlélet. Ám - ahogyan azt az előző részben részletesen kifejtettük - az eszközök, erőforrások megléte önmagában nem biztosítja azt, hogy azokkal az emberek el is érik az értékesnek tartott tevékenységeket/létállapotokat. Ezért az eszközök vizsgálatát nem lehet elválasztani a használatot befolyásoló tényezők azonosításától. Például hiába van sűrű tömegközlekedési hálózata egy városnak, ha nincsenek alacsony padlós járművek és a megállók nincsenek akadálymentesítve, akkor a lakosok egy része (aki mozgáskorlátozott) kimarad a tömegközlekedés használatából, és nem fogja elérni a városon belüli mobilitás képességét. Az emberek helyzetét tehát a rendelkezésükre álló lehetőségek és az őket akadályozó korlátok szemszögéből kell megítélni. Hasonlóképpen hiába van jogi lehetősége egy civil szervezetnek a városfejlesztési dokumentumok véleményezésére, ha 500 oldalnyi anyag áttekintésére 3 munkanap áll rendelkezésére.

A harmadik lépés a megvalósított beavatkozás hatásainak értékelése a képességek szemszögéből és ennek visszacsatolása a fejlesztési folyamatba. Azt kell értékelni, hogy a beavatkozás valóban hozzájárult-e a képességek kiteljesítéséhez, valóban a kívánt képességekhez járult-e hozzá, illetve a nem szándékolt hatások nem eredményezték-e más képességek erodálódását (Biggeri, Ferrannini 2014a). Ez a lépés tehát tulajdonképpen visszacsatolás arra vonatkozóan, hogy a fejlesztési beavatkozás létrehozta-e az első lépésben meghatározott lehetőségeket. Az ilyen értékelés során szerzett tudás pedig alapvető eleme lesz a későbbi tervezésnek.

Fontos hangsúlyozni, hogy a helyi gazdaságfejlesztés folyamata dinamikus. Az előbbi lépések folyamatos ismétlésére van szükség ahhoz, hogy a helyben élők képességei gyarapodjanak. Ennek három oka van:

- A közösség számára értékesnek tartott célok közötti fontossági sorrend nincs kőbe vésve, a társadalmi folyamatoknak megfelelően változik. Ezért van szükség a célok és értékek folyamatos felülvizsgálatára.

- A helyi gazdaságfejlesztés folyamata komplex társadalmi valóságban történik. Vagyis elképzelhető, hogy a fejlesztés során olyan átváltási tényezők jelennek meg, amelyekre nem számítottak (számíthattak) a fejlesztők. Az újonnan megjelent átváltási tényezők hatását pedig be kell építeni a fejlesztés folyamatába.

- A folyamatos részvétel során a helyi gazdaságfejlesztés szereplői is változáson mennek keresztül: lehetőségük van tanulni, ezért jó eséllyel tapasztaltabbak, aktívabbak lesznek, egyre jobban átlátnak folyamatokat, ami hozzásegíti őket a sikeresebb helyi gazdaságfejlesztéshez. 


\section{A helyi gazdaságfejlesztés határai és döntéshozatali eljárásai}

A képességszemlélet alapján megfogalmazott kiindulópont alapvető hatással van a helyi gazdaságfejlesztés vizsgálati területére, más tudományterületekhez való viszonyára, a szakértői tudás és a politikai színtér viszonyáról alkotott felfogásra, illetve munkamódszerére (célszerűnek látszó döntéshozatali eljárásaira). Ebben a részben e témák mentén kíséreljük meg felvázolni a helyi gazdaságfejlesztés körvonalait a képességszemlélet alapján.

\section{A helyi gazdaságfejlesztés vizsgálati területe}

A helyi gazdaságfejlesztés szakirodalma széles körüen tárgyalja, hogy mi tartozik vizsgálati területébe és hogyan különül el más tudományterületektől (Bajmócy 2011; G. Fekete 2008; Lengyel 2010; Mezei 2006; Pike, Rodrigez-Pose, Tomaney 2006). A képességszemléletből kiindulva mindez nem elsődleges fontosságú kérdés. Minthogy a jóllétet számos gazdasági és nem gazdasági tényező, valamint azok összetett kapcsolatrendszere együttesen befolyásolja, így a helyi gazdaságfejlesztés, a helyi fejlesztés vagy a településfejlesztés határai elmosódnak.

Ugyanakkor jó okkal lehet amellett érvelni, hogy a jóllét sokszínűségét megragadó fejlesztési elképzelést fölösleges gazdaságfejlesztésnek hívni. ${ }^{8}$ Mindemellett fontos és értelmes dolog lehet a gazdasági folyamatokat specifikusan is vizsgálni és arról részletes tudásanyagot építeni. Már csak azért is, mivel azt a képességszemlélet sem állítja, hogy a gazdasági lehetőségek bővülése ne vezethetne sok esetben a helyi lakosok képességeinek kiszélesedéséhez.

Ilyen értelemben tehát elfogadhatjuk, hogy a helyi gazdaságfejlesztés továbbra is a gazdasági folyamatok vizsgálatára (megértésére, értékelésére és megváltoztatására) helyezi a hangsúlyt. A képességszemlélet azonban e tekintetben sajátos kérdésfeltevéseket kínál. Egyrészt kontextusba helyezi a gazdasági folyamatokkal való foglalkozást. A felmerülő problémák megoldása kapcsán sokszor nem feltétlenül a jövedelemnövelés, hanem esetleg más képességek bővítése vagy éppen csak az elosztás megváltoztatása tủnik fontos feladatnak (Sen 1999a). Másrészt - ami talán az előbbinél is lényegesebb - felhívja a figyelmet a gazdasági és nem gazdasági tényezők közötti kapcsolat vizsgálatának fontosságára. A nagyobb jövedelem (versenyképesség, innovációs képesség stb.) elérhető más képességek erodálása révén is; illetve azok csak akkor értékesek, ha a személyes és környezeti átváltási tényezők lehetővé teszik, hogy kiszélesítsék a helyben élők képességeit. A gazdasági folyamatokkal való kizárólagos foglalkozás helyett tehát a képességszemlélet a gazdasági és nem gazdasági tényezők kapcsolatának mélyreható elemzését javasolja.

Nem tartjuk tehát gyümölcsözőnek azt az általánosan elterjedt megközelítést (pl. Európai Területfejlesztési Perspektíva, Európa 2020 stratégia, S3 stratégiák), amely hatékonysági, méltányossági és fenntarthatósági dimenziókra 
osztja a valóságot, és az egyes aspektusokat adott szakterületekhez rendeli (pl. gazdaságfejlesztés, társadalompolitika, környezetpolitika). Különösen a gazdaságfejlesztés - korábban elemzett - pozitivista retorikája mentén válik ez a megközelítés problematikussá. Ugyanis úgy tűnhet, mintha a gazdaságfejlesztésre vonatkozó állítások tényállítások, míg a fenntarthatóság és méltányosság értékválasztási kérdések volnának - azaz foglalkozni kell velük, de a gazdaságfejlesztéstől függetlenül.

\section{A helyi gazdaságfejlesztés döntéshozatali eljárásai}

Azzal, hogy a helyi gazdaságfejlesztés alapvető céljaként a helyben élők helyzetének javítását nevezi meg, szükségszerüen interdiszciplináris és problémaközpontú megközelítés mellett kötelezi el magát. Ahogyan azt az előző alpontban kifejtettük, nem a szakterületek elkülönítésén, hanem a köztük lévő kapcsolatok, szinergiák és konfliktusok feltárásán van a hangsúly.

Ám a képességszemlélet alapú helyi gazdaságfejlesztés nem elégedhet meg azzal, hogy felismeri az interdiszciplinaritás szükségességét. A jóllét és általában a közösség által értékesnek tartott szempontok középpontba helyezése sokféle tudásforma érvényességének elfogadását igényli. A tudományos (szakértői) tudás-eloállításon túl a helyi (laikus) tudás is hatalmas jelentőségre tesz szert. A helyi gazdaságfejlesztés e megközelítésben tehát transzdiszciplináris, problémamegoldó folyamat.

E folyamat jelentősen eltér a normál tudományos problémamegoldás terepétől. A helyi gazdaságfejlesztés olyan posztnormál szituációban zajlik, ahol a tényeknek többféle (érvényes) interpretációja létezhet, kikerülhetetlenek az értékválasztási döntések, a bizonytalan helyzetben meghozott döntések megerősíthetik, de akár ki is kezdhetik a fennálló struktúrákat (ilyen értelemben nagy a döntések tétje), és jellemzően azelőtt kell javaslatot tenni és döntéseket hozni, hogy a letisztult tudományos (szakértői) tudás-előállításhoz elegendő idő állna rendelkezésre (Funtowitz, Ravetz 1993; Ravetz 2004).

Egy ilyen közegben a döntést segítő szakértői javaslatok ötvözik a hagyományos tudományos tudás-előállítás és a politikai cselekedetek jellemzőit. Már pusztán azzal, hogy megválasztják az értékelés információs bázisát (a figyelembe vett és figyelmen kívül hagyott információk körét), elköteleződnek bizonyos jóléti (vagy jólléti) felfogás mellett, és ezáltal értékterheltté válik a szakértői munka. A képességszemlélet alapján ez nem problémának, hanem természetes jelenségnek tűnik. A probléma akkor lép fel, ha ez az értékelköteleződés nem válik felfedhetővé, nem tehető nyílt viták tárgyává.

A szakértői tudás hangsúlyozása a szakirodalomban egybefonódik az érintettek részvételének hangsúlyozásával (Callon, Lascoumes, Barthe 2011; Pataki 2007). A szakértői és helyi (laikus) tudás nem egymás helyettesítői, hanem kiegészítői. A szakértői-laikus együttműködésen alapuló technikákra a problé- 
mamegodás új módozatai mellett a szakpolitikai tanulás új irányaként is tekinthetünk (Elekes, Bajmócy 2013). E technikák helyi fejlesztésben történő alkalmazásáról egyre több tapasztalat áll rendelkezésre, például a részvételi költségvetés, az állampolgári tanács, a normatív jövőképalkotás (backcasting), a részvételi akciókutatás (Pataki 2007).

Ennek megfelelően a deliberatív részvétel hiánya kedvezőtlenül hat a szakértői tevékenység minőségére, hiszen a szükséges tudás egy része nem tud becsatornázódni a folyamatba (Bajmócy, Gébert 2014), ráadásul könnyen azt is eredményezi, hogy a szakértői javaslatok politikai tartalma homályba burkolózik. Ez viszont rontja a politikai szféra hatékonyságát, hiszen az érték- és érdekelköteleződés részben láthatatlanná válik, kikerüli a politikai vitákat (Callon, Lascoumes, Barthe 2011).

A képességszemléletre alapozó fejlesztési megközelítések alapvető fontosságúnak tekintik az érintettek (elsősorban állampolgárok) részvételét a fejlesztési folyamatban. Sen (1999a) megközelítésében a részvétel eszköz ahhoz, hogy az emberek hathatósabban érjék el céljaikat, de eszköz voltától függetlenül önmagában is értékkel bíró képesség. Mindennek jelentős elméleti megalapozását adja azzal, hogy rámutat a preferenciák aggregálásából kiinduló szavazásorientált döntési eljárások hiányosságaira, és elemzi a deliberatív társadalmi döntéshozatalban rejlő előnyöket (Pataki 1998; Sen 1999b).

A részvételi döntéshozatali eljárásokkal kapcsolatban széles körű szakirodalom áll rendelkezésre, amely érvek és ellenérvek sokaságát sorakoztatja fel. Ez a vita a helyi fejlesztés hazai szakirodalmában is élénken folyik (Bajmócy, Gébert 2014; Csanádi, Csizmady, Kőszeghy 2010; Földi 2009; Reisinger 2010; Szirmai, Szépvölgyi 2007). Tanulmányunkban nem közvetlen célunk a deliberatív részvétel fontossága melletti érvek és ellenérvek ütköztetése. A képességszemlélet melletti elköteleződés elengedhetetlenné teszi a deliberatív részvételen alapuló döntéshozatali eljárásokat (Crocker 2007). A képességszemléleten alapuló helyi gazdaságfejlesztésben a részvétel gyakorlati nehézségei nem igazolhatják a részvétel elhagyását (Bajmócy, Gébert 2014). A részvétel problémái ezzel együtt nem söpörhetők szőnyeg alá, fontos ösztönzést adhatnak az alkalmazott technikák módosításához, új technikák megalkotásához.

\section{A helyi gazdaságfejlesztés gyakorlatának hazai tapasztalatai}

Ebben a részben felvázoljuk a képességszemlélet melletti elköteleződés néhány gyakorlati következményét. Ennek során igyekszünk olyan témákat érinteni, amelyeknek vannak közvetlen magyarországi kapcsolódásai. Az a célunk, hogy kézzelfoghatóbbá tegyük korábbi elméleti érveinket, rávilágítsunk a képességszemlélet és az eszközorientált megközelítés jelentős különbségeire. Mindennek nemcsak elméleti jelentősége van, hanem segíteni kívánjuk a helyi gazdaságfejlesztés gyakorlati problémáinak megoldását is. 


\section{Eszközök és célok a helyi gazdaságfejlesztés gyakorlatában}

Általános tapasztalat, hogy a helyi fejlesztési beavatkozások nem mindig hozzák meg a várt eredményt. A hazai városok helyi fejlesztési dokumentumait vizsgálva szembeötlő, hogy a tervezett konkrét fejlesztési lépések (például a turisztikai kínálat bővítése, ipari parkok fejlesztése, új termelő beruházások átadása, egyetem-ipari kapcsolatok erősítése, vállalatok technológiafejlesztésének segítése, munkahelyteremtésre adott kedvezmények) tételesen megvalósulnak, a projektek monitoringindikátorai megfelelnek az előzetes célkitűzéseknek, ennek ellenére a koncepciókban kijelölt hosszú távú célokhoz sokszor mégsem jutnak közelebb a városok. Az sem ritka, hogy a tervezők és a helyi politikusok legjobb szakmai és etikai meggyőződéssel kimunkált projektötletei egyes csoportok elégedetlenségével vagy akár jelentős civil ellenállással találkoznak.

A képességszemlélet szakirodalma sok olyan külföldi helyi fejlesztési projektről számol be, amelyek az eszközorientált megközelítésben sikeresnek mondhatóak, de nyilvánvaló ellentmondások jelentkeztek velük kapcsolatban, és a képességek szempontjából már egyáltalán nem tűnnek sikertörténetnek (Gébert 2015). Például a brazil favellák lakói részére épített, közművekkel ellátott kőházakat a projekt befejezését követően a lakók elkezdték bontani, az áram-, ivóvíz- és szennyvízhálózatról pedig lecsatlakoztak. Az afrikai falvakban fúrt ivókutakat a projekt végeztével a helybeli asszonyok lerombolták. Egy indonéz törzs tagjainak, miután falujuk egy természeti csapás következtében megsemmisült, új házakat építettek, amelyeket szinte azonnal önként elhagytak a „kedvezményezettek”. Szintén nem volt sikertörténet, amikor a lakóházak energiaellátását célzó projekt eredményeként a női munkanap hossza jelentősen megnőtt, hiszen immár sötétedés után is tudtak dolgozni (Gébert 2015).

Ugyan az előbb említett projektek nem az Európai Unió területén valósultak meg, ennek ellenére számos tanulsággal szolgálhatnak a hazai fejlesztési gyakorlat számára. Például rávilágítanak arra, hogy milyen kulturális értékek befolyásolják a fejlesztés résztvevőit a létrejött infrastruktúra használatában, vagy hogy mely átváltási tényezők játszanak közre egy fejlesztési folyamatban. Kevés a képességszemlélet alapján elemzett hazai gazdaságfejlesztési projekt, de kimutatható, hogy az ilyen típusú problémák a hazai fejlesztési gyakorlatra is jellemzőek (Gébert 2015).

Az eszközorientált helyi gazdaságfejlesztés egyik jellemzője, hogy az eszközök létrehozására fókuszál és nem azok használatára. Azaz a fejlesztési folyamat értékeléséből általában kimarad minden olyan elem, amely arra vonatkozna, hogy a létrehozott eszközök miként befolyásolták az érintettek életét, vagyis hogy az érintettek ténylegesen mit tehetnek meg, mit érhetnek el az új eszközök használatával.

Emiatt érzéketlen az eszközorientált helyi gazdaságfejlesztés a fejlesztési projekten túl mutató hatásokkal szemben. Mivel a helyi gazdaságfejlesztés a komplex valóságban zajlik, a projekteknek könnyen lehet előre nem látott ha- 
tása. Ez még valószínủbb, ha a tervezés során nem törekedtek az információs bázis kiszélesítésére. Ráadásul a projektek maguk is megváltoztathatják a helyi viszonyokat, másfajta alkalmazkodást hívhatnak életre (például a szereplők számítanak bizonyos támogatási formákra), vagy az átváltási tényezők megváltozását hozhatják magukkal (például ha a felújított helyi piacon a magasabb bérleti díjak miatt hátrányba kerülnek az őstermelők a kereskedőkhöz képest).

Amennyiben a fejlesztési folyamatot kizárólag abból a szemszögből ítéljük meg, hogy létrejöttek-e a tervezett eszközök, akkor sok fontos információt hagyhatunk figyelmen kívül. Nem vehetjük észre, hogy a projekt esetleg milyen képességek megszüntetését eredményezte, vagy milyen hatással volt azokra az érintettekre, akiket a tervezés és monitoring során nem azonosítottunk érdekcsoportként.

\section{Érvek a társadalmi részvétel mellett a közéleti passzivitás országában}

A képességszemlélet a passzív befogadó helyett aktív cselekvő szerepet szán az érintetteknek (köztük elsősorban a helyi lakosoknak). Ugyanakkor igen erős szkepticizmus tapasztalható ezzel kapcsolatban mind a tudományos, mind pedig a hazai közéleti vitákban. Egyrészt gyakran szokás hivatkozni a civil szféra gyengeségére, az ilyen hagyományok hiányára, a demokrácia fiatal voltára, az érdektelenségre, a kompetencia hiányára, a helyi politikai elit és a helyi nagyvállalkozók domináns szerepére. A fejlesztőket is számos kudarcélmény éri. Az érintettek bevonására irányuló kísérletek érdektelenségbe fulladnak, meddő vitákat hoznak, vagy szakmailag vállalhatatlan eredményekre vezetnek. Ráadásul a lakosság sok esetben még akkor sem mozgósítható, amikor egy-egy fejlesztési projekt akár közvetlen hatással van rájuk (Bodorkós et al. 2006). A közéleti passzivitás annak ellenére jellemző Magyarországra, hogy a társadalmi részvétel formáinak ismertsége relatíve magas (Ferencz 2015).

A képességszemlélet segítséget nyújt az említett érvek, problémák rendszerezéséhez. Egyrészt rámutat arra, hogy nem a korlátozások hiányára, hanem a tényleges lehetőségre kell figyelmünket irányítani. Például attól, hogy korábban az építési törvényben vagy jelenleg a partnerségi egyeztetési tervekben elvi lehetőséget adunk a részvételre, még nem biztos, hogy a szereplők ténylegesen is részt vehetnek. Ezt olyan átváltási tényezők akadályozhatják, mint például a szakmai zsargonnal teletűzdelt szövegek, a hierarchiát tükröző partnerségi találkozók (pulpitusra ültetett tervezők, városházi helyszín), a szűkös véleményezési határidők vagy az észrevételek - szakértői jellegü - szöveges megfogalmazásának elvárása.

A képességszemlélet felhívja tehát a figyelmet a valódi részvétel képességének feltételeire. A rossz tapasztalatok jelentős része könnyen lehet, hogy a téves elvárásokból (túl precíz, szakértő hozzájárulás elvárása), az alkalmatlan, deliberációt nélkülöző technikák használatából (például közmeghallgatás, la- 
kossági fórum, ötletbörze) eredt. Számos gyakorlati példa bizonyítja ugyanis, hogy a deliberációt előtérbe helyező technikák sok esetben sikerrel alkalmazhatók magas és alacsony jövedelmű térségekben is (Pataki 2007).

További fontos üzenet, hogy az érintettek egyaránt hozzájárulhatnak a tudás-előállításhoz és a közösségi döntések meghozatalához. Ezt természetesen ellehetetleníti, ha olyan körülményeket hozunk létre, ahol eleve nem ezt, hanem a fejlesztők érveinek, döntéseinek elfogadását várjuk az érintettektől. Hogy ez mennyire nem idegen a hazai gyakorlattól, arra kiválóan utal a társadalmi részvételre alkalmazott hazai „szakkifejezés”: a társadalmasítás.

Saját ügyeink tevékeny előmozdítását természetesen az is ellehetetleníti, ha bizonyos alapvető képességeknek nem vagyunk birtokában. A fejlesztési folyamat kikerülhetetlen eleme az ilyen képességhiányok megszüntetése. Így a deliberatív részvétel szorosan kapcsolódik a képessé tétel (empowerment) ideájához (Kesby 2005).

\section{Interdiszciplinaritás melletti érvek a szakmai elkülönülés világában}

Magyarországon a helyi fejlesztés jogszabályi háttere szinte kőbe vési a diszciplináris elkülönülést. Ezt szolgálja egyrészt a tervezés és rendezés éles szétválasztása (1997. évi LXXVIII. törvény; 314/2012. kormányrendelet). Ám ezt még inkább erősíti a fejlesztési tervek tartalmi követelményeinek részletes meghatározása. Az elő́rások egymástól elválasztott részekre osztják a helyi fejlesztés komplex valóságát, és azt intézményesítik, hogy ezeket a szempontokat elkülönülten kell kezelni, ami helyenként különböző dokumentumtípusokat, míg más esetben egy dokumentumon belüli, különálló fejezeteket jelent.

A képességszemlélet olyan tervezési megközelítést kínál, ahol a fejlesztési javaslatokat nem egymástól elkülönülten értékelik. Ez nem jelenti azt, hogy egyetlen holisztikus tervben összegződne minden fejlesztési javaslat. Ez nyilvánvalóan gyakorlati problémákat vetne fel. Inkább úgy képzeljük el, hogy a közösségek vízióalkotással kezdik a tervezési folyamatot, amelynek szerves része az értékesnek tartott képességekről folytatott nyílt vita.

Mindez alapot adhat az iteratív, folyamatos tanuláson és deliberáción alapuló helyi fejlesztési folyamatnak. Az egyes fejlesztési részterületek értékelhetővé válnak az értékesnek tartott képességek fényében, a viták pedig hozzájárulhatnak a közösségi vízió finomításához, megváltozásához. E tapasztalatokat azután a szakértők is mind jobban képesek beépíteni saját munkájukba, így a nyílt viták eredményre vezethetnek.

Mindez nem hoz létre problémamentes ideális állapotot, de úgy véljük, hogy megközelítésünk egyszerre segítheti elő a szakpolitikai tanulást és a demokratikus gyakorlatok megerősödését, a korábbinál szélesebb teret nyújthat a problémák felismerésére és az információs bázis új szempontokkal történő kiegészítésére. 


\section{Összegzés és következtetések}

Tanulmányunkban a helyi gazdaságfejlesztés egyik lehetséges koncepcióját körvonalaztuk. Abból indultunk ki, hogy minden helyi gazdaságfejlesztés célja a helyben élők helyzetének a javítása. Ám a szakirodalom nagy része nem határozza meg pontosan e végső célt, ami számos probléma forrásává válik. Ezek közül az egyik legfontosabb, hogy a helyi gazdaságfejlesztés szokásos megközelítései a célok helyett az eszközök biztosítására fókuszálnak. Azzal a feltételezéssel élnek, hogy az eszköz (például a jövedelem) birtoklása automatikusan elvezet a célok eléréséhez.

1. táblázat: Az eszközorientált és a képességszemléleten alapuló helyi gazdaságfejlesztés összevetése Comparison of local economic development in the means-oriented and capability approach

\begin{tabular}{|c|c|c|}
\hline Szempont & $\begin{array}{l}\text { A helyi gazdaságfejlesztés } \\
\text { eszközorientált megközelítése }\end{array}$ & $\begin{array}{l}\text { Helyi gazdaságfejlesztés a } \\
\text { képességszemlélet alapján }\end{array}$ \\
\hline Kiindulópont & Célnak tekintett eszközök. & $\begin{array}{l}\text { A közösség számára fontosnak } \\
\text { tekintett képességek } \\
\text { meghatározása. }\end{array}$ \\
\hline $\begin{array}{l}\text { A célok megfelelőségének } \\
\text { vizsgálata }\end{array}$ & $\begin{array}{l}\text { A végső célokat a politikai színtéren } \\
\text { jelölik ki, így azok vizsgálata nem } \\
\text { része a helyi gazdaságfejlesztésnek. } \\
\text { A célok mögött meghúzódó } \\
\text { előfeltevések homályba burkolása és } \\
\text { hallgatólagos elfogadása jellemző. }\end{array}$ & $\begin{array}{l}\text { A „megfelelő” célok } \\
\text { helyspecifikusak, azokat csak } \\
\text { társadalmi részvétel és nyílt } \\
\text { megvitatás útján lehet kijelölni. } \\
\text { A célok kijelölésének módja része a } \\
\text { helyi gazdaságfejlesztés vizsgálati } \\
\text { területének; az értékelköteleződés } \\
\text { nyílt. }\end{array}$ \\
\hline $\begin{array}{l}\text { Az eszköz és a cél } \\
\text { feltételezett viszonya }\end{array}$ & $\begin{array}{l}\text { A szükséges eszközök birtoklása } \\
\text { automatikusan elvezet a célok } \\
\text { eléréséhez. }\end{array}$ & $\begin{array}{l}\text { Az eszközök nem feltétlenül } \\
\text { válthatók át célokká. }\end{array}$ \\
\hline Az elemzés fókusza & $\begin{array}{l}\text { Az eszközök (elsősorban } \\
\text { reáljövedelem) biztosításának } \\
\text { módja. }\end{array}$ & $\begin{array}{l}\text { Mit tudnak ténylegesen kezdeni a } \\
\text { helyi lakosok a rendelkezésre álló } \\
\text { eszközökkel? } \\
\text { (A közösség által jó okkal értékesnek } \\
\text { tekintett képességek + a célokhoz } \\
\text { rendelt eszközök + átváltási } \\
\text { tényezők.) }\end{array}$ \\
\hline $\begin{array}{l}\text { A releváns tudás } \\
\text { elóállitásának módja }\end{array}$ & $\begin{array}{l}\text { Szakértői (tudományos) tudás- } \\
\text { előállítás, melyet a politikai } \\
\text { döntéshozatal vagy figyelembe vesz, } \\
\text { vagy nem. } \\
\text { A szakértői tudás érték- és } \\
\text { érdeksemlegesnek tekintése. }\end{array}$ & $\begin{array}{l}\text { A versengő szakértői álláspontok } \\
\text { mellett a helyi érintettek kezében } \\
\text { szétszórtan meglevő helyi (laikus) } \\
\text { tudás is releváns. } \\
\text { A szakértői tudás posztnormál } \\
\text { felfogása. }\end{array}$ \\
\hline
\end{tabular}

Forrás: saját szerkesztés. 
Kutatásunk középpontjában a cél és az eszköz viszonyának tisztázása állt, ehhez a kortárs jóléti közgazdaságtan egyik legmarkánsabb irányzatát, Amartya Sen képességszemléletét használtuk fel. Elköteleződésünk tette lehetővé, hogy újraértelmezzük és valós tartalommal töltsük meg a helyi gazdaságfejlesztés célmeghatározását. Elemzésünkből egy problémaközpontú, inter- és transzdiszciplináris megközelítés bontakozott ki.

Álláspontunkat több helyen ütköztettük a helyi gazdaságfejlesztés szokásos (általunk eszközorientáltnak nevezett) megközelítésével. (1. táblázat).

A képességszemlélet alapján lehetséges tehát olyan helyi gazdaságfejlesztés, mely egyaránt fókuszál a célra, az eszközökre és azok használatára, illetve a fejlesztési folyamat mögött homályban maradó értékválasztás helyett nyíltan értékvezérelt, közösségközpontú megközelítést kínál. E folyamatnak lényegi eleme, hogy a közösség által fontosnak tartott képességeket (amelyhez a helyi gazdaságfejlesztés hozzá kíván járulni) a különböző, explicitté tett értékek alapján, deliberatív részvétel útján határozzák meg.

A képességszemlélet-alapú helyi gazdaságfejlesztés azt hangsúlyozza, hogy a jelenlegi fejlesztési gyakorlat során figyelembe vett információk nem elegendőek, továbbá hogy a sikeres helyi gazdaságfejlesztés nem korlátozódhat egyetlen szempontra, például csak a gazdasági növekedésre. Tehát az általunk javasolt megközelítés az információs bázis kiszélesítéséhez kínál iránymutatást.

\section{Jegyzetek}

1 Tanulmányunkban a továbbiakban különbséget teszünk a jólét (welfare) és a jóllét (well-being) között az angol nyelvű szakirodalomnak megfelelően. E fogalmak közötti különbségre a harmadik részben térünk ki.

2 A „capability” kifejezés képességként fordítása a magyar nyelvben félrevezeto, mert a „képesség” kifejezés elsősorban az egyén személyes tudására, készségeire utal. Ezzel szemben a „capability" kifejezés együttesen jelenti a személyes jellemzők és a megfelelő környezet meglétét.

3 A másik módszer az előre rögzített lista használata. Ennek lényege, hogy etikai elvek alapján összeállítható a képességeknek egy olyan felsorolása, amely univerzális listaként müködhet minden értékelés során (Nussbaum 2000, 2011). Tanulmányunk terjedelmi korlátai miatt erre a megoldásra nem tudunk részletesen kitérni.

4 A Kaldor (1939), Hicks (1939) és Scitovszky (1941) féle kettős kompenzációs kritérium értelmében.

5 Ez tulajdonképpen a tényállítások (van) és erkölcsi ítéletek (kell); a pozitív és normatív tudomány Hume-ig visszavezethetö elkülönítése.

6 Nehezen hihető például, hogy a hatályos hazai joganyag a közgazdaságtani elméletalkotás eredményeitől függetlenül határozta volna meg a településfejlesztés céljaként a versenyképességet (1997. évi LXXVIII tv. 7.\$).

7 Igen érdekes a foglalkoztatásnövelési cél megjelenésének elmélettörténeti vizsgálata. Az 1940-es évekig a kapitalista berendezkedésű országokban senki sem tartotta a kormány feladatának a foglalkoztatottság növelését - a munkanélküliség által okozott társadalmi károk mérséklését igen, de magát a foglalkoztatottság növelését nem (Hands 2009). Az csak azután került a kormány felelősségi körébe, miután levezették a keynesi gondolatrendszerből, hogy a kormánynak vannak eszközei a magasabb szintű foglalkoztatottság eléréséhez. A gazdaságel- 
méletből kiderült, hogy a kormány képes gazdasági eszközökkel elérni egy olyan célt, amely addig kívül esett a közgazdaságtan tudományterületén; így ez a társadalmi cél is bekerült a gazdaságfejlesztés elméletébe.

8 Ezzel alapvetően egyetértünk, és úgy véljük, hogy az a fajta megközelítés, amelyet „helyi fejlesztésnek" szokás nevezni (G. Fekete 2008; Mezei 2006), a gyakorlatban sokszor gyümölcsözőbb, mint a gazdasági folyamatokra való kizárólagos koncentrálás.

\section{Köszönetnyilvánítás}

Hasznos tanácsaikért köszönettel tartozunk a két anonim bírálónak, valamint Elekes Zoltánnak, Gyurkovics Jánosnak, Juhász Juditnak, Juhász Sándornak, Méreiné Berki Boglárkának, Tőzsér Jánosnak és Vas Zsófiának. Tanulmányunk az OTKA K 109425 („A helyi gazdaságfejlesztés megalapozása a képességszemlélet segítségével" címü) projekt keretében készült.

\section{Irodalom}

Alkire, S. (2007): Why the capability approach? Journal of Human Development, 1., 115-135.

Bajmócy Z. (2011): Bevezetés a helyi gazdaságfejlesztésbe. JATEPress, Szeged

Bajmócy Z., Gébert J. (2014): Arguments for deliberative participation in local economic development. Acta Oeconomica, 3., 313-334. http://doi.org/bgd9

Biggeri, M., Ferrannini, A. (2014a): Opportunity gap analysis: Procedures and methods for applying the capability approach in development initiatives. Journal of Human Development and Capabilities, 1. , 60-78. http://doi.org/bgfb

Biggeri, M., Ferrannini, A. (2014b): Sustainable human development. A new territorial and people-centred perspecitve. Palgrave Macmillan, New York

Bodorkós B., Kajner P., Kovács E., Peták P., Péterfi F. (2006): RAJTunk múlik! Hogyan szervezkedjünk és képviseljük érdekeinket a lakóhelyünkön. Közösségfejlesztők Egyesülete, Budapest

Callon, M., Lascoumes, P., Barthe, M. (2011): Acting in an uncertain world. An essay on technical democracy. The MIT Press, Cambridge, London

Crocker, D. A. (2007): Deliberative participation in local development. Journal of Human Development, 3., 431-455. http://doi.org/dsjvmx

Csanádi G., Csizmady A., Kőszeghy L. (2010): Nyilvánosság és részvétel a településtervezési folyamatban. Tér és Társadalom, 1., 15-36.

Elekes Z., Bajmócy Z. (2013): Regionális innovációpolitika és szakpolitikai tanulás a komplex rendszerek elméletének szemszögéből. In: Inzelt A., Bajmócy Z. (szerk.): Innovációs rendszerek. Szereplók, kapcsolatok és intézmények. JATEPress, Szeged, 244-262.

Faragó L. (2005): A jövőalkotás társadalomtechnikája. A közösségi tervezés elmélete. Dialóg Campus Kiadó, Budapest, Pécs

Ferencz Z. (2015): A társadalmi részvétel és a nagyváros-térségi versenyképesség. In: Szirmai V. (szerk.): A területi egyenlőtlenségektól a társadalmi jól-lét felé. Kodolányi János Főiskola, Székesfehérvár, 327-348.

Földi Zs. (2009): A társadalmi részvétel szerepe a városfejlesztés gyakorlatában. Európai és hazai tapasztalatok. Tér és Társadalom, 3., 27-43.

Frediani, A. A. (2010): Sen's capability approach as a framework to the practice of development. Development in Practice, 2., 173-187. http://doi.org/dk4f23 
Funtowitz, S. O., Ravetz, J. R. (1993): Science for the post-normal age. Futures, 7., 739-755. http://doi.org/fqntk9

G. Fekete É. (2008): Együtt! De hogyan? Kistérségi tervezés. Észak-Magyarországi Regionális Fejlesztési Ügynökség, Miskolc

Garami E. (2009): A humán erőforrás területi különbségei. Területi Statisztika, 3., 281-298.

Gébert, J., Málovics, G., Fáskerti, Zs. (2012): The limits of well-being measurement at sub-regional level. Regional Statistics, 2., 45-57. http://doi.org/bgfc

Gébert J. (2015): Helyi gazdaságfejlesztés a képességszemlélet alapján. Doktori értekezés. Szegedi Tudományegyetem Gazdaságtudományi Kar, Szeged

Hands, D. W. (2009): The positive-normative dichotomy and economics. In: Maki, U. (ed.): Philosophy of Economics. Elsevier, Amsterdam, 219-239.

Hausman, D. M., McPherson, M. S. (1996): Economic analysis and moral philosophy. Cambridge University Press, Cambridge

Hicks, J. R. (1939): The foundations of welfare economics. The Economic Journal, 196., 696-712. http://doi.org/fgzch2

Kaldor, N. (1939): Welfare propositions of economics and interpersonal comparisons of utility. The Economic Journal, 195., 549-552. http://doi.org/bbqjsf

Kesby, M. (2005): Retheorizing empowerment-through-participation as a performance in space: Beyond tyranny to transformation. Journal of Woman in Culture and Society 4., 2037-2065. http://doi.org/bsmvw9

Latour, B. (1993): We have never been modern. Harvard University Press, Cambridge

Latour, B. (2005): Reassembling the social. An introduction to actor-network-theory. Oxford University Press, Oxford, New York

Layard, R. (2006): Happiness: Lessons from a new science. Penguin, London

Lengyel B., Bajmócy Z. (2013): Regionális és helyi gazdaságfejlesztés az evolúciós gazdaságföldrajz szemszögéből. Tér és Társadalom, 1., 5-29.

Lengyel I. (2010): Regionális gazdaságfejlesztés. Versenyképesség, klaszterek és alulról szerveződő stratégiák. Akadémiai Kiadó, Budapest

Mezei C. (2006): A helyi gazdaságfejlesztés fogalmi meghatározása. Tér és Társadalom, 4., 85-96.

N. Kovács T. (2015): A jól-lét alapú társadalmi versenyképességi modell elméleti összefüggései. In: Szirmai V. (szerk.): A területi egyenlőtlenségektól a társadalmi jól-lét felé. Kodolányi János Főiskola, Székesfehérvár, 81-95.

Nagy G., Koós B. (2014): First results in modelling objective well-being in Hungary at lower territorial level. Regional Statistics, 2., 71-86. http://doi.org/bgfd

Nussbaum, M. (2000): Woman and human development: The capabilities approach. Cambridge University Press, Cambridge http://doi.org/bgff

Nussbaum, M. (2011): Creating capabilities: the human development approach. Belknap Press of Harvard University Press, Cambridge http://doi.org/bgfg

Pataki Gy. (1998): A fejlődés gazdaságtana és etikája. Tiszteletadás Amartya Sen munkásságának. Kovász, 4., 6-17.

Pataki Gy. (2007): Bölcs „laikusok”. Civil Szemle, 3-4., 144-156.

Pike, A., Rodriguez-Pose, A., Tomaney, J. (2006): Local and regional development. Routledge, London, New York

Ravetz, J. R. (2004): The post-normal science of precaution. Futures, 3., 347-357. http://doi.org/dmz3nr

Rawls, J. (1971): A theory of justice. The Belknap Press of Harvard University Press, Cambridge

Rawls, J. (1982): Social unity and primary goods. In: Sen A. K., Williams, B. (eds.): Utilitarianism and beyond. Cambridge University Press, Paris, 159-186. http://doi.org/d6zdq6

Rawls, J. (2001): Justice as fairness: A restatement. The Belknap Press of Harvard University Press, Cambridge, London

Reisinger A. (2010): Társadalmi részvétel a helyi fejlesztéspolitikában - különös tekintettel a civil/nonprofit szervezetek szerepére. Doktori értekezés, SZE Regionális- és Gazdaságtudományi Doktori Iskola, Győr

Robeyns, I. (2005): The capability approach: a theoretical survey. Journal of Human Development and Capabilities 1., 93-117. http://doi.org/d6wqr5 
Robeyns, I. (2006): The capability approach in practice. The Journal of Political Philosophy, 3., 351-376. http://doi.org/btxmft

Scitovszky, T. (1941): A note on welfare propositions in economics. The Review of Economic Studies, 1., 77-88. http://doi.org/cp7kgt

Samuelson, P. A., Nordhaus, W. D. (2009): Közgazdaságtan. Akadémiai Kiadó, Budapest

Sen, A. K. (1979): The welfare basis of real-income comparisons: A survey. Journal of Economic Literature, 1., 1-45.

Sen, A. K. (1993): Capability and well-being. In Nussbaum, M., Sen A. K. (eds.): The quality of life. Clarendon Press, Oxford, 30-53. http://doi.org/cp5nbh

Sen, A. K. (1995): Inequality reexamined. Cambridge University Press, Cambridge http://doi.org/dr9rqm

Sen, A. K. (1999a): Development as freedom. Oxford University Press, Oxford, New York

Sen, A. K. (1999b): The possibility of social choice. American Economic Review, 3., 349-378. http://doi.org/cmhh6g

Sen, A. K. (2008): Capabilities, lists, and public reason: Continuing the conversation. Feminist Economics, 3., 77-80.

Stiglitz, J. E., Sen, A. K., Fitoussi, J. P. (2009): Report by the commission on the measurement of economic performance and social progress. http://www.insee.fr/fr/publications-et-services/dossiers_ web/stiglitz/doc-commission/RAPPORT_anglais.pdf (Letöltés: 2016. január 15.)

Swinburn, G., Goga, S., Murphy, F. (2006): Local economic development: A primer. Developing and implementing local economic development strategies and action plans. The World Bank, Washington

Szirmai V., Szépvölgyi Á. (2007): Társadalmi részvétel szereplői. In: Rechnitzer J. (szerk.): Település és fejlesztés. A közszolgáltatások hatékonyságának növelése a településfejlesztésben. Magyar Közigazgatási Intézet, Budapest, 89-104.

Szirmai V. (2015): A területi egyenlőtlenségektól a társadalmi jól-lét felé. Kodolányi János Főiskola, Székesfehérvár 